\title{
SISTEM SINKRONISASI DAN MONITORING LALU LINTAS KOMODITAS PERTANIAN UNTUK MENGURANGI KESALAHAN INFORMASI
}

\author{
Leonard Onnanda Soli ${ }^{1}$, Anjik Sukmaaji ${ }^{2}$, Teguh Sutanto ${ }^{3}$ \\ ${ }^{1,2}$ Jurusan S1 Sistem Informasi Fakultas Teknologi Informasi Universitas Dinamika \\ Jl. Raya Kedung Baruk 98 Surabaya, 60298 \\ ${ }^{1}$ leonard,soli27@gmail.com \\ 2 anjik@dinamika.ac.id \\ ${ }^{3}$ teguh@dinamika.ac.id
}

\begin{abstract}
Abstrak
Dalam rangka pencegahan masuk, tersebar dan keluarnya Hama Penyakit Hewan Karantina (HPHK) dan Organisme Pengganggu Tumbuhan Karantina (OPTK) balai karantina memegang peranan penting. Mekanisme tersebut harus dilakukan dengan melakukan monitoring lalulintas komunitas seteliti mungkin agar tidak terjadi permasalahan di pelaksana pertanian, yakni para petani. Kecepatan proses monitoring dan pengawasan diperlukan suatu sistem terkomputerisasi yang dapat mensinergikan data-data untuk menjadi informasi yang akurat kepada badan pengawasan. Data observasi yang dilakukan di Balai Karantina Pertanian Kelas II Ternate (BARANTAN) digunakan sebagai obyek simulasi sistem monitoring dan sinkronisasi data pengawasan lalulintas komuditas. Dari hasil pengumpulan data, dalam pelaksanaanya terdapat beberapa permasalahan yang dimana dalam kegiatan monitoring data lalu lintas komoditas sering terjadi crash dan duplikasi data lalu lintas pertanian yang menimbulkan ketidak akurasian data dalam kegiatan lalu lintas komoditas pertanian. Selain itu, penerapan sistem rekapitulasi manual dengan excel menyebabkan lambatnya proses pemenuhan permintaan data lalu lintas pertanian, dimana data tersebut digunakan sebagai bahan kajian bagi beberapa instansi pemerintahan. Berdasarkan permasalahan tersebut, dilakukanlah proses perancangan dan pembangunan aplikasi lalu lintas komoditas pertanian untuk mengatasi permasalahan yang ada. Untuk mengurasi kesalahan informasi proses sinkronisasi dilakukan dengan sistem yang terintegrasi yang harus dibangun menggunakan aplikasi berbasis komputer. Sistem yang dibangun berorientasi pada integrasi data transaksi aplikasi utama dengan sistem informasi monitoring. Sistem informasi dibangun dalam visualisasi daskboard yang memudahkan dalam pemantauan dan pengawasan. Informasi yang dihasilkan terkait dengan kegiatan monitoring data melalui grafik data lalu lintas pertanian dan mempercepat kegiatan rekapitulasi data pergerakan lalu lintas pertanian yang ada dalam lingkup kerja balai pengawasan dan karantina.
\end{abstract}

Kata kunci: monitoring, integrasi, karantina, dashboard.

\section{PENDAhUluan}

Dalam kegiatan pengawasan lalu lintas komoditas pertanian Balai Karantina Pertanian Kelas II Ternate memiliki beberapa kendala yang memperlambat proses perekapan dan pengontrollan data lalu lintas komoditas pertanian, adapun beberapa kendala yang ada seperti belum dapat mengumpulkan data secara langsung dari setiap wilker. Berdasarkan hal itu, dibutuhkan waktu kurang lebih 1-2 minggu menyelesaikan proses rekapitulasi data. Selain itu, belum adanya sistem aplikasi yang menampilkan grafik perkembangan lalu lintas pertanian membuat sulitnya kegiatan pemantauan tingkat laju perkembangan lalu lintas komoditas pertanian yang terjadi di wilayah Maluku Utara. Akibat adannya kendala tersebut, sering terjadi crash dan duplikasi data pada data kegiatanlalu lintas komoditas pertanian. Selain itu ditemukan pula beberapa permasalahan pada pemenuhan permintaan data rekapitulasi, dimana Balai Karantina Pertanian Kelas II Ternate sulit dan lambat untuk memenuhi permintaan data dari beberapa instansi pemerintahan seperti Badan Pusat Statistik (BPS), Kantor Layanan Pajak Maluku Utara, serta Pusat Data dan Informasi Kemetrian Pertanian 
(PUSDATIN), yang dimana instansi-instansi tersebut membutuhkan data lalu lintas komoditas yang akan digunakan sebagai bahan pencatatatan laporan statistik bulanan maupun tahunan dalam penyusunan laporan lalu lintas komoditas pertanian di wilayah Maluku Utara.

Melalui penelitian ini, diharapkan dapat lebih mempermudah kegiatan pemantauan lalu lintas komoditas dari setiap wilker dan juga mempermudah kegiatan rekapitulasi data-data tersebut sebagai bahan dokumentasi dan evaluasi, serta dapat dijadikan sebagai sumber data resmi untuk memenuhi kebutuhan permintaan data lalu lintas komoditas pertanian dari beberapa instansi pemerintahan, yang dimana data-data tersebut digunakan sebagai bahan dalam penyusunan laporan statistik lalu lintas komoditas pertanian serta sebagai acuan dalam penggambaran grafik laju lalu lintas komoditas pertanian di wilayah Maluku Utara. Berdasarkan penjelasan di atas, perancangan aplikasi ini akan memberikan beberapa fitur dan kemudahan seperti pengelolaan data per bulan dari setiap wilker yang dapat membantu mempercepat proses kegiatan rekapitulasi data lalu lintas komoditas pertanian dan juga penyediaan fitur gambaran grafik dari tingkat pergerakan lalu lintas komoditas pertanian di wilayah Maluku Utara..

\section{METODOLOGI PENELITIAN}

Untuk menyelesaikan permasalahan tentang perlunya sistem terintegrasi dan monitoring pada balai karantina dilakukan pendekatan pengembangan sistem Sistem Development Live Scyle (SDLC) dengan metode waterfall. Dipilihnya metode pengembangan sistem waterfall karena (1) memiliki proses yang urut, mulai dar analisa hingga support, (2) Setiap proses memiliiki spesifikasinya sendiri, sehingga sebuah sistem dapat dikembangkan sesuai dengan apa yang dikehendaki (tepat sasaran), (3) Setiap proses tidak dapat saling tumpang tindih.

Rancangan sistem berbasis pada obyek oriented programming yaitu Uniffied Modelling Language (UML). Dari analisis kebutuhan atau Functional Requirement yang sudah dilakukan pada obyek penelitian yakni :

a) Superviser membutuhkan sebuah sistem yang dapat mengontrol dan membaca hasil laporan data lalu lintas komoditas pertanian dari setiap wilker. Baik berupa inputan domestik masuk maupun keluar yang didalamnya mencakup objek hewan dan tumbuhan.

b) Administrator wilker membutuhkan sebuah sistem aplikasi yang dapat menginputkan, mengedit dan melihat informasi data domestik masuk dan keluar baik berupa hewan maupun tumbuhan dalam lingkup wilker masing-masing. Selain itu setiap administrator wilker diharapkan dapat memantau perkembangan grafik lalu lintas pertanian pada bagian wilker masing-masing.

Dari Functional Requirement tersebut selanjutnya dibuat rancangan use case diagram seperti pada Gambar 1. Pada Gambar 1 tersebut, pengguna dan sistem yang telah dirancang dimana pada bagian ini menjelaskan hak akses dan kegiatan yang dapat dan tidak dapat dilakukan oleh setiap user baik itu user yang pengelola aplikasi maupun user eksternal. Pada bagian tahap ini menyajikan beberapa fitur yang nantinya akan disajikan pada perancangan dan pengembangan aplikasi lalu lintas komoditas pertanian. Pada use case ini menggambarkan interaksi antara supervisor dan administrator wilker serta pihak instansi lainnya seperti yang ada pada Gambar 1. Use Case Diagram Rancangan Sistem.

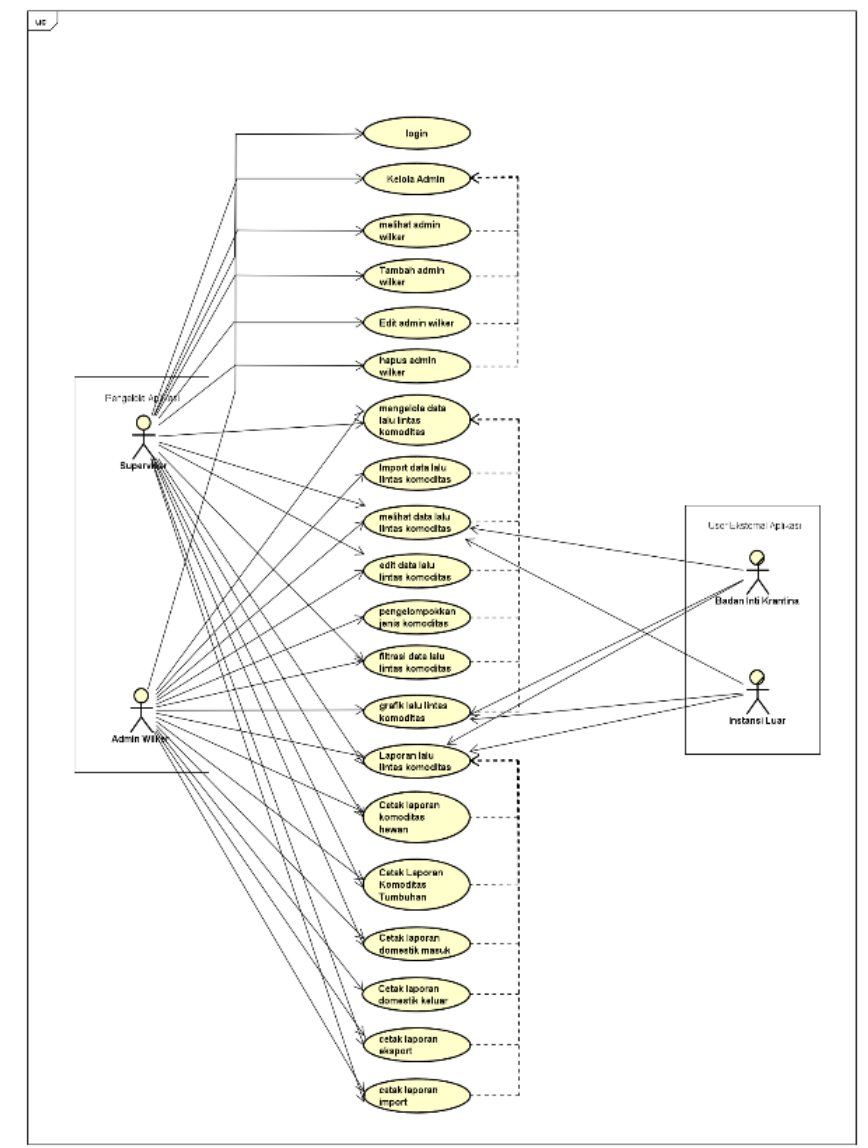

Gambar 1. Use Case Sistem Monitoring Lalu lintas Komoditas Pertanian.

Dari hasil use case diagram selanjutnya dibuat beberapa rancangan rancangan activity diagram. Pada bagian ini akan menggambarkan alur kegiatan dari setiap dari setiap aktifitas yang nantinya akan disajikan pada perancangan dan pengembangan aplikasi lalu lintas komoditas pertanian. Pada activity diagram ini akan menggambarkan beberapa aktifitas diantaranya: login, pembuatan akun wilker, import data lalu lintas komoditas pertanian, edit data lalu lintas komoditas pertanian, hapus data lalu lintas komoditas pertanian dan pencetakkan data lalu lintas komoditas pertanian.

a) Activity Login

Pada activity ini menggambarkan proses login dari dua user yakni supervisor dan administrator wilker. Proses ini diawali dengan menginputkan username dan password 
kemudian akan dilakukan proses validasi untuk mengecek kesesuaian data inputan dengan data pada database seperti yang ada pada Gambar 2. Activity Login.

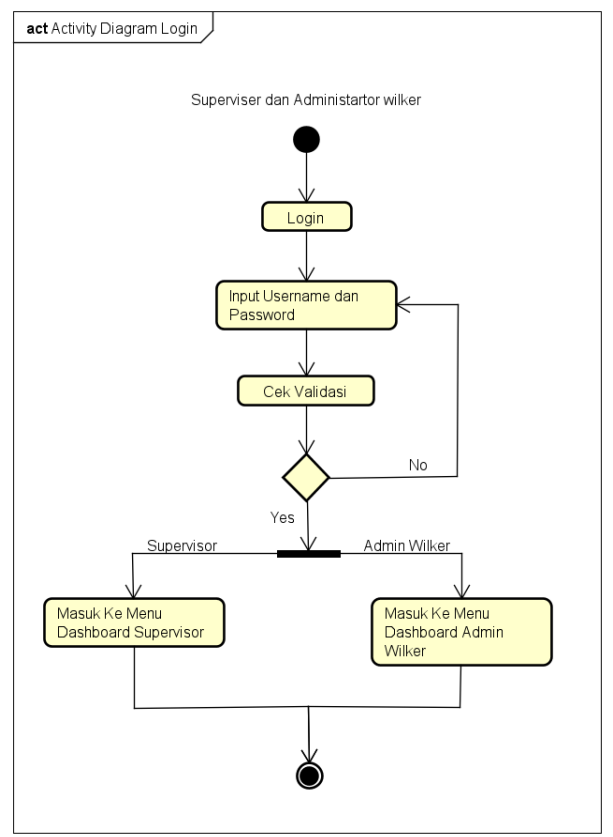

Gambar 2. Activity Login

b) Activity Pembuatan Akun Administrator Wilker

Pada activity ini menggambarkan proses pembuatan akun bagi setiap wilker yang dimana hal ini hanya dapat dilakukan oleh supervisor seperti pada Gambar 3. Langkah awal dimana supervisor akan melakukan kegiatan login seperti pada penjelasan Activity Login. Setelah supervisor itu masuk ke halaman daftar administrator dan melakukan beberapa pengisian form sebagai syarat pembuatan akun administrator setelah itu supervisor dapat melakukan proses penyimpanan data administrator baru seperti yang ada pada Gambar 3. Activity Penambahan Administrator.

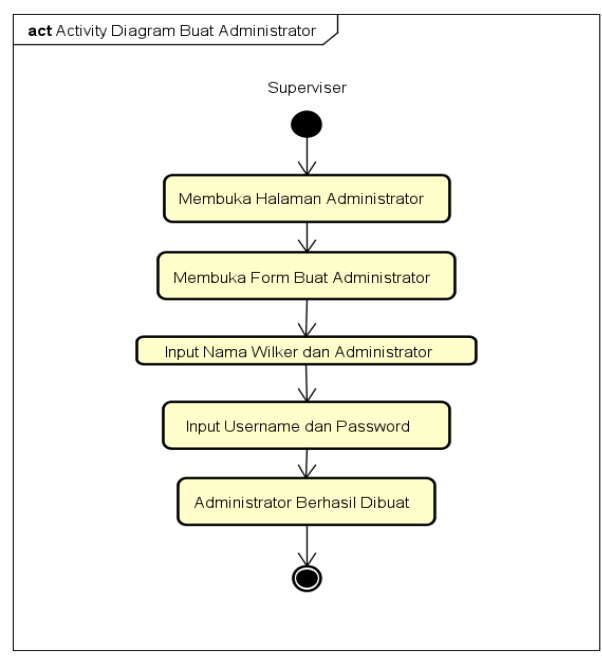

Gambar 3. Activity Penambahan Administrator c) Activity Penginputan Data Lalu lintas Komoditas Pertanian

Pada activity ini menggambarkan alur kegiatan penambahan data lalu lintas komoditas pertanian yang hanya dapat dilakukan oleh user administrator wilker seperti pada Gambar 4. Pada kegiatan ini para administrator wilker akan melakukan proses penginputan data lalu lintas komoditas pertanian yang ada pada setiap wilker. Data lalu lintas komoditas yang diinputkan terdiri dari jenis komoditas, jalur pengiriman komoditas, jumlah komoditas, dan total PNBP seperti yang ada pada Gambar 4. Activity Penginputan Data Lalu lintas Komoditas Pertanian.

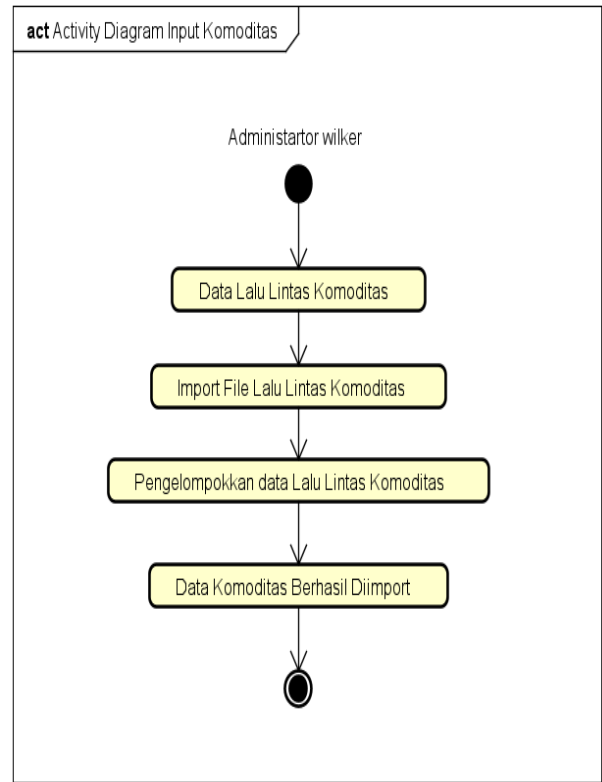

Gambar 4. Activity Penginputan Data Lalu lintas Komoditas Pertanian.

d) Activity Edit Data Lalu lintas Komoditas Pertanian

Pada activity ini menggambarkan proses pengeditan dari setiap data lalu lintas komoditas yang dianggap kurang sesuai dimana proses ini dapat dilakukan oleh dua user yakni supervisor dan administrator wilker seperti pada Gambar 5. Pada kegiatan ini akan dilakukan proses pengeditan pada setiap data yang memiliki kesalahan pada proses penginputan sebelumnya seperti kesalahan pada jenis komoditas, jalur komoditas, jumlah komoditas dan juga total PNBP dari setiap komoditas. Dalam penerapannya user supervisor dapat melakukan pengeditan data dari seluruh wilker namun user administrator wilker hanya dapat melakukan pengeditan dar data wilker sendiri seperti yang ada pada Gambar 5. Activity Edit Data Lalu lintas Komoditas Pertanian. 


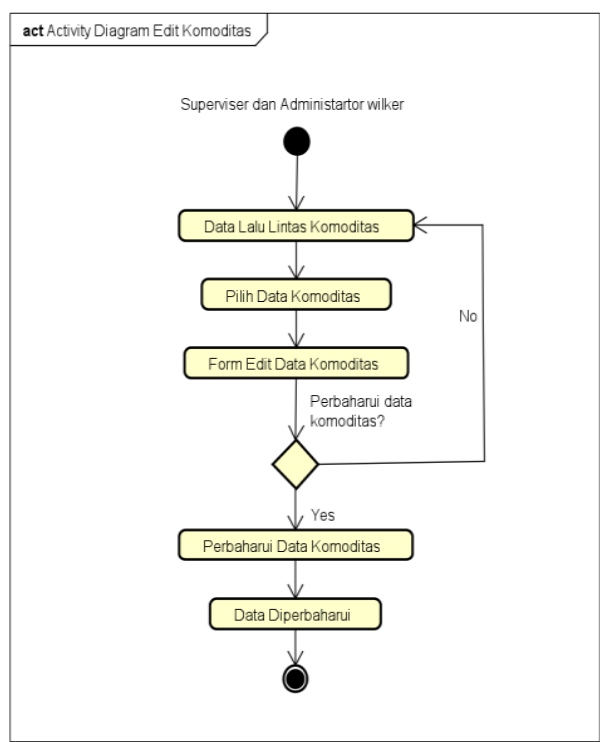

Gambar 5. Activity Edit Data Lalu lintas Komoditas Pertanian

e) Activity Hapus Data Lalu lintas Komoditas Pertanian Pada activity ini menggambarkan kegiatan penghapusan data yang dianggap tidak valid dari setiap data lalu lintas komoditas pertanians seperti pada Gambar 6. Kegiatan ini akan melakukan penghapusan keseluruhan informasi dari data lalu lintas komoditas yang tidak valid guna mencegah terjadinya duplikasi data maupun kesalahan lainnya. Kegiatan ini hanya dapat dilakukan oleh user supervisor seperti yang tampak pada Gambar 6. Activity Hapus Data Lalu lintas Komoditas Pertanian.

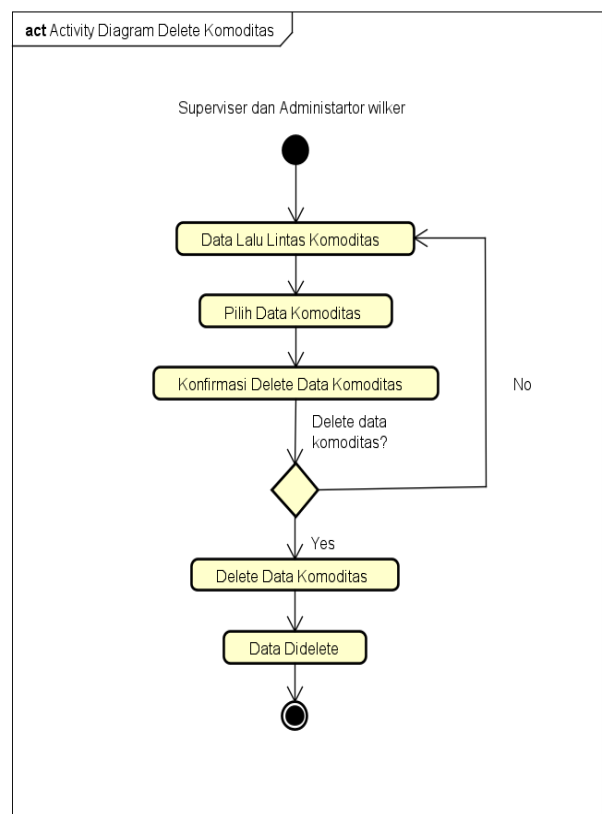

Gambar 6. Activity Hapus Data Lalu lintas Komoditas Pertanian f) Activity Cetak Data Lalu lintas Komoditas Pertanian Pada activity ini menggambarkan kegiatan pencetakan data lalu lintas komoditas yang telah diinputkan dimana proses ini dapat dilakukan oleh dua user yakni supervisor dan administrator wilker sepert pada Gambar 7. Pada kegiatan ini akan dilakukan proses pencetakan laporan data lalu lintas komoditas berdasaarkan rentang tanggal lalu lintas, jenis komoditas, dan jalur komoditas. Dalam penerapannya user supervisor dapat melakukan pencetakan laporan data dari seluruh wilker tetapi user administrator wilker hanya dapat melakukan pencetakan laporan data wilker berdasarkan area kerja wilker masing-masing seperti yang ada pada Gambar 7. Activity Cetak Data Lalu lintas Komoditas Pertanian.

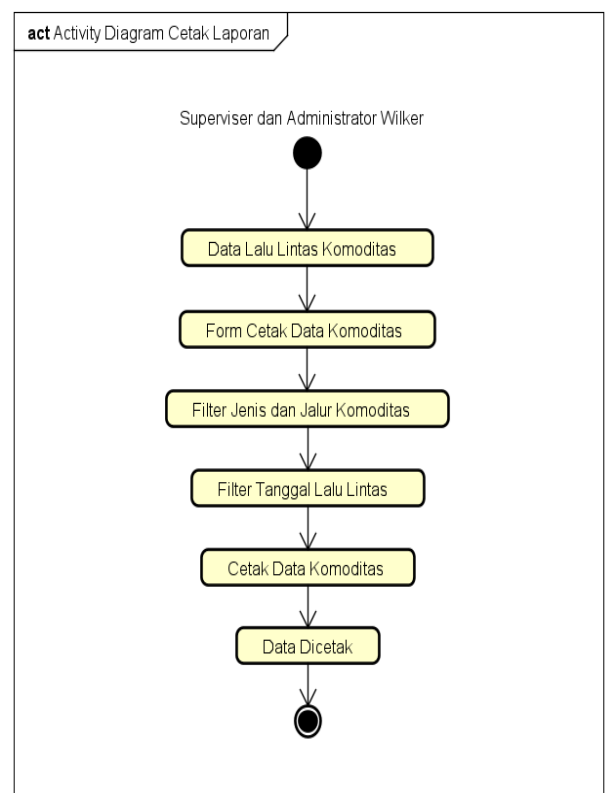

Gambar 7. Activity Cetak Data Lalu lintas Komoditas Pertanian.

Setelah perancngan activity diagram selanjutnya dibuat beberapa rancangan rancangan sequence diagram. Pada bagian ini akan menggambarkan interaksi antar user dan objek-objek yang ada pada perancangan sistem monitoring lalu lintas komunitas pertanian.

a) Sequence Login

Pada sequence ini memperlihatkan hal-hal yang diperlukan untuk melakukan login. Pada Gambar 8, dijelaskan proses login yang dimulai ketika kedua aktor masuk ke halaman login dengan menggunakan username dan password, setelah itu akan dilakukan proses autentikasi pada sistem aplikasi, setelah melakukan proses autentikasi dan mendapatkan data dari setiap user, maka setiap user akan diarahkan kebagian dashboard sesuai dengan data yang miliki seperti yang ada pada Gambar 8. Sequence Login. 


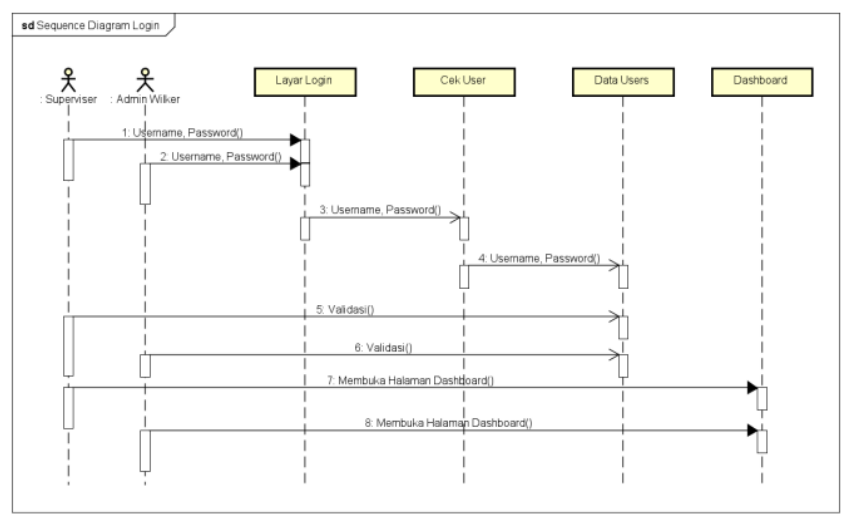

Gambar 8. Sequence Login

b) Sequence Pembuatan Akun Administrator Wilker

Pada sequence ini akan menggambarkan alur pembuatan sebuah akun baru yang akan digunakan oleh setiap wilker seperti pada Gambar 9. Adapun aktor yang berperan pada bagian ini adalah supervisor. Proses ini dimulai pada halaman form penambahan admin wilker dimana pada bagian ini supervisor akan memasukkan data setiap admin wilker yang diantaranya nama wilker, email wilker, lokasi wilker, penanggung jawab wilker dan username wilker, serta password yang akan digunakan setiap admin untuk mengakses aplikasi. Setelah data tervalidasi dan tersimpan ke dalam database, selanjutnya supervisor akan diarahkan ke bagian daftar administrator wilker seperti pada Gambar 9. Sequence Pembuatan Akun Administrator Wilker.

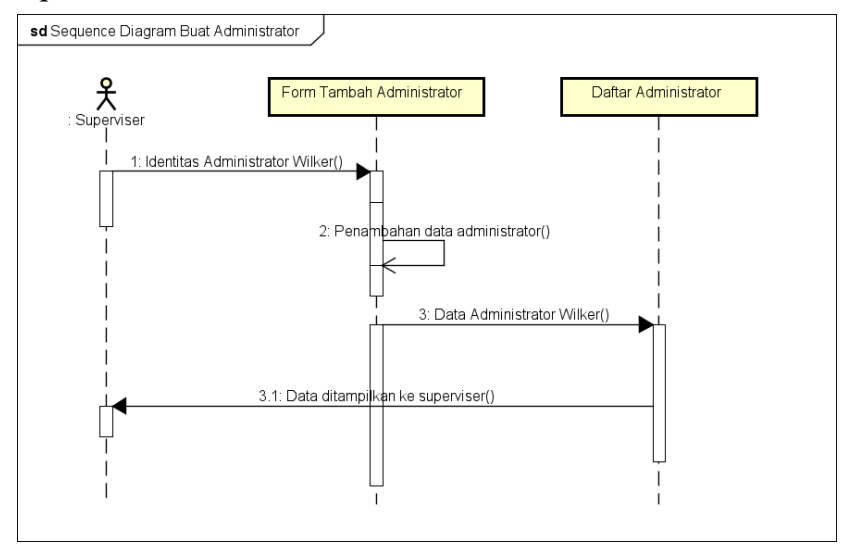

Gambar 9. Sequence Pembuatan Akun Administrator Wilker

c) Sequence Input Data Lalu lintas Komoditas Pertanian

Pada sequence ini ini dijelaskan proses impor data lalu lintas komoditas dimana disana terdapat seorang aktor yakni administrator wilker seperti pada Gambar 10. Pada bagian ini dibutuhkan sebuah data hasil ekspor dari iQfast yang berupa file excel. Data tersebut digunakan sebagai bahan inputan ketika administrator wilker masuk pada bagian form impor data. Proses selanjutnya dimana data tersebut akan divalidasi dan data tersebut akan dimasukkan ke dalam database berdasarkan lokasi dari masing-masing wilker seperti yang ada pada Gambar 10. Sequence Input Data Lalu lintas Komoditas Pertanian.

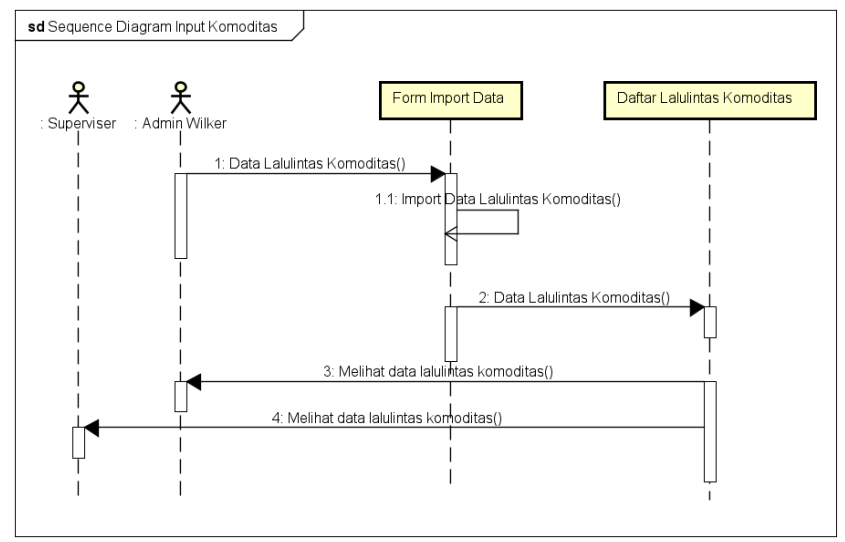

Gambar 10. Sequence Input Data Lalu lintas Komoditas Pertanian

d) Sequence Edit Data Lalu lintas Komoditas Pertanian

Pada sequence ini dijelaskan proses edit dari setiap data lalu lintas komodotas pertanian seperti pada Gambar 11. Pada kegiatan ini terdapat dua aktor yakni supervisor dan administrator wilker serta dua objek yaitu daftar lalu lintas komoditas dan form edit. Langkah awal dimana setiap aktor akan diarahkan kebagian daftar lalu lintas komoditas setelah itu setiap aktor dapat memilih data-data yang akan diedit setelah itu, para aktor akan diarahkan kebagian form edit data lalu lintas komoditas dan melakukan proses editing seperti pada Gambar 11. Sequence Edit Data Lalu lintas Komoditas Pertanian.

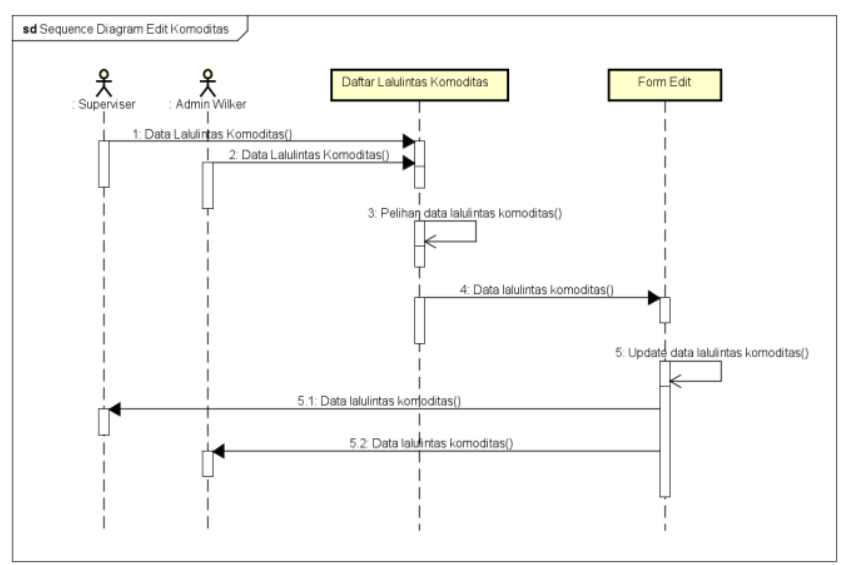

Gambar 11. Sequence Edit Data Lalu lintas Komoditas Pertanian

e) Sequence Hapus Data Lalu lintas Komoditas Pertanian Pada sequence ini dijelaskan proses penghapusan data lalu lintas komoditas pertanian, dimana terdapat dua aktor yakni supervisor dan administrator wilker serta sebuah objek daftar lalu lintas komoditas seperti pada Gambar 12. Langkah awal dimana setiap aktor akan diarahkan kebagian daftar lalu lintas komoditas setelah itu setiap aktor dapat memilih data-data yang akan dihapus setelah itu, para aktor akan melakukan 
proses penghapusan data lalu lintas komoditas dengan menekan tombol hapus. Pada tahap akhir setiap aktor akan diarahkan kembali pada halaman daftar lalu lintas komoditas pertanian seperti yang ada pada Gambar 12. Sequence Hapus Data Lalu lintas Komoditas Pertanian.

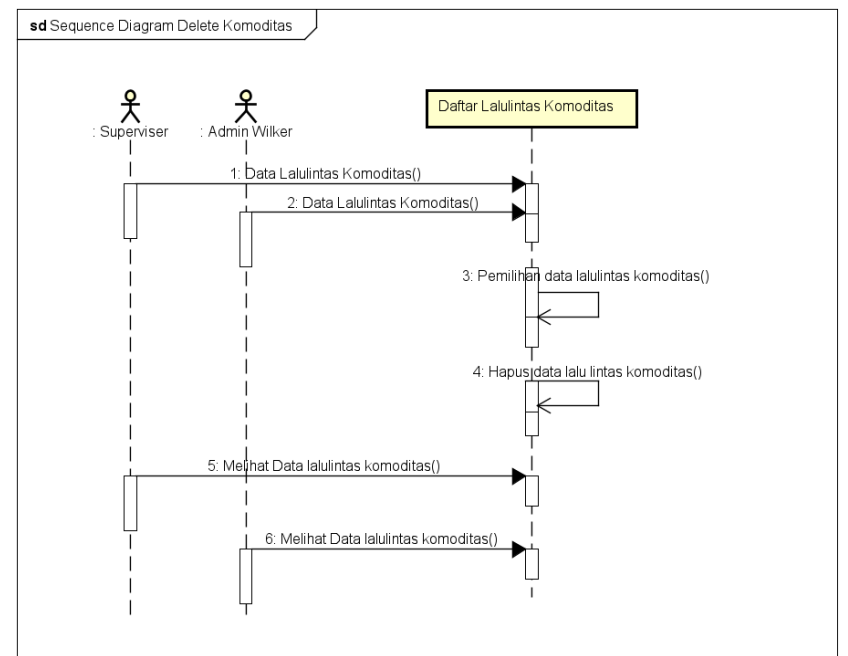

Gambar 12. Sequence Hapus Data Lalu lintas Komoditas Pertanian.

f) Sequence Cetak Data Lalu lintas Komoditas Pertanian

Pada sequence ini dijelaskan proses pencetakan data lalu lintas komodotas pertanian yang dimana terdapat dua aktor yakni supervisor dan administrator wilker serta dua objek yaitu form cetak laporan dan laporan lalu lintas komoditas sepeti pada Gambar 13. Langkah awal dimana aktor akan diarahkan ke bagian laporan lalu lintas komoditas, setelah itu akan dilakukan proses filtrasi dimana proses ini dibatasi berdasarkan hak akses dari masing-masing aktor. Dimana supervisor dapat melakukan filtrasi secara berdasarkan data keseluruhan wilker serta jenis dan jalur komoditas. Sedangkan aktor administrator wilker hanya dapat melakukan filtrasi berdasarkan jenis dan jalur komoditas yang ada pada wilker masing-masing seperti yang ada pada Gambar 13 . Sequence Cetak Data Lalu lintas Komoditas.

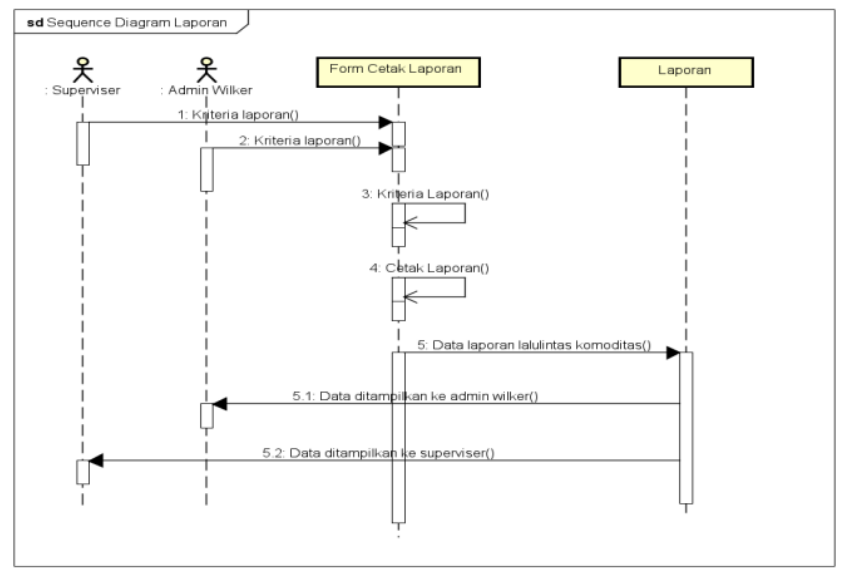

Gambar 13. Sequence Cetak Data Lalu lintas Komoditas
Dari Sequence Diagram selanjutnya dibuat rancangan class diagram seperti pada Gambar 14. Pada gambar tersebut, menunjukkan keterkaitan antar class dalam proses perancangan sistem monitoring lalu lintas komoditas pertanian dan menjelaskan bagaimana setiap class akan saling berkolaborasi untuk membangun suatu tujuan. Pada bagian ini diperlihatkan komponen class, atribut, metode, dan hubungan dari setiap objek yang diperlukan untuk menghasilkan sistem monitoring lalu lintas komoditas pertanian. Berikut merupakan gambaran class diagram yang ada pada perancangan sistem monitoring lalu lintas komoditas pertanian.

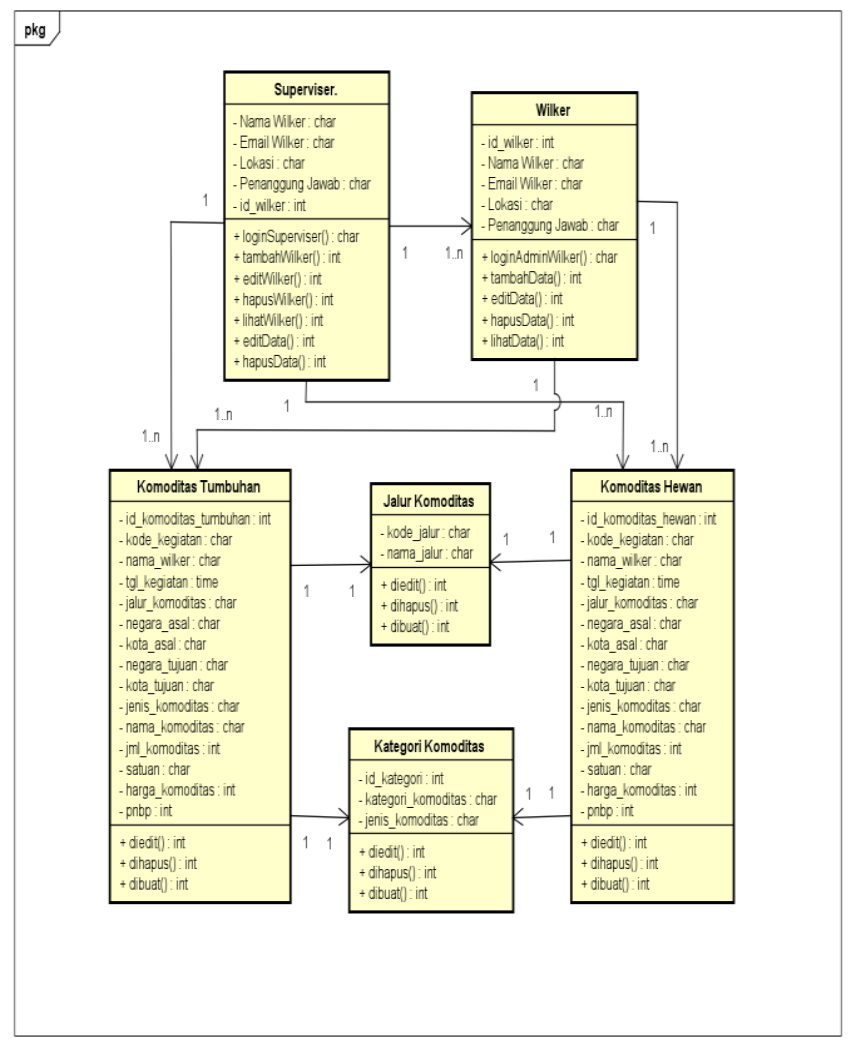

Gambar 14. Class Sistem Monitoring Lalu lintas Komoditas Pertanian

\section{HASIL DAN PEMBAHASAN}

\section{A. Hasil Implementasi}

Halaman monitoring dashboard merupakan gambaran grafik yang bersumber dari hasil inputan data lalu lintas komoditas, dimana data tersebut telah melalui proses validasi, dan pengelompokkan sesuai dengan ketentuan yang telah dibuat pada proses desain sistem. Bagian ini dapat membantu menunjukkan tingkatan perkembangan lalu lintas komoditas pertanian, dimana data yang disajikan dalam bentuk grafik yang mudah di baca dan dipahami. Pada bagian ini akan membagi data berdasarkan jenis komoditas hewan, komoditas tumbuhan dan jalur lalu lintas yang dilalui. 


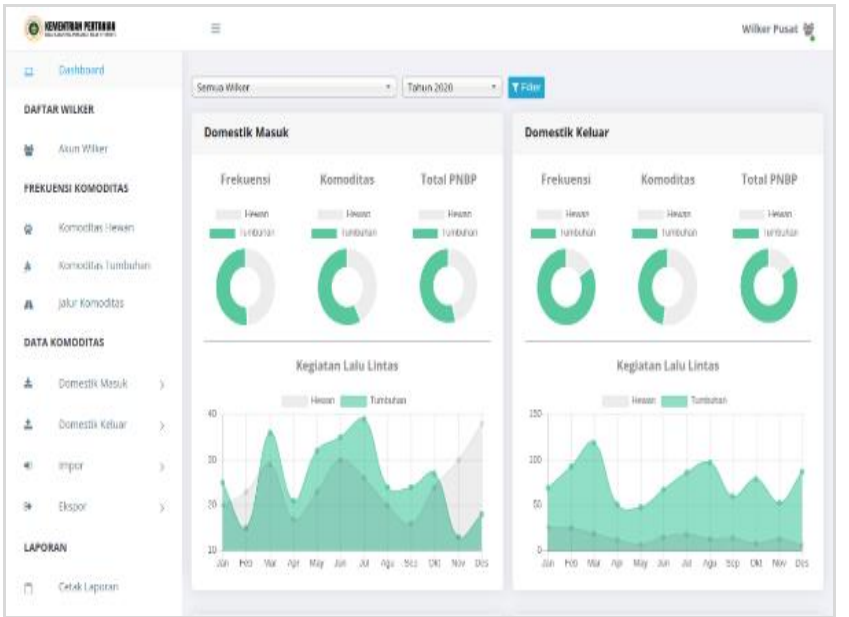

Gambar 15. Dashboard Grafik Lalu Lintas Komoditas Pertanian

Pada halaman komoditas hewan yang pada Gambar 16, akan menampilkan hasil berupa tabel rincian komoditas hewan yang dimana pada bagian ini mengelompokkan seluruh data hewan baik itu yang masuk maupun keluar dari wilayah Maluku Utara. Dalam pengelompokkan itu, terbagi menjadi beberapa kategori diantaranya Hewan, Bahan Asal Hewan (BAH), Hasil Bahan Asal Hewan (HBAH) dan Benda Lainnya. Pada tabel ini akan diperlihatkan nama dan jumlah komoditas.

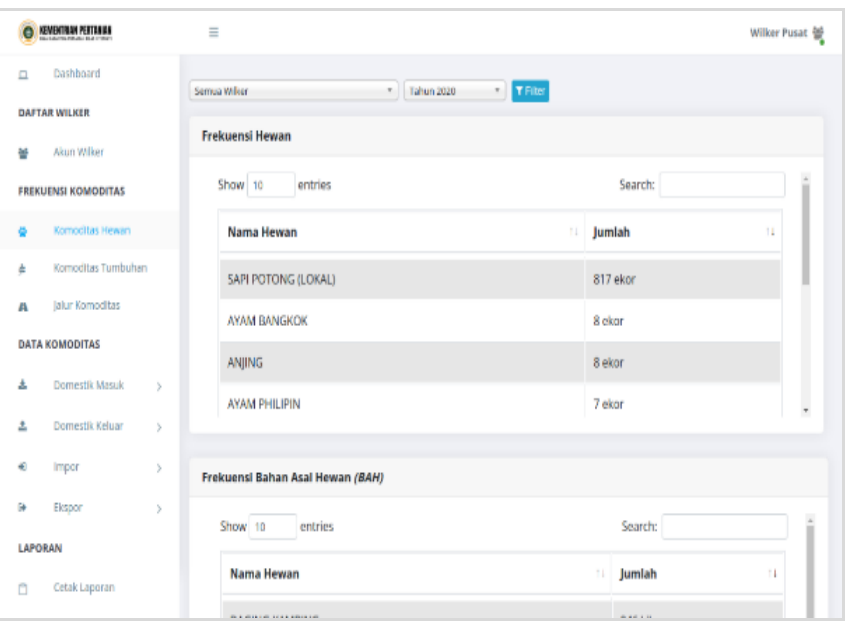

Gambar 16. Frekuensi Rincian Komoditas Hewan

Pada halaman komoditas Tumbuhan yang pada Gambar 17, akan menampilkan hasil pengelompokkan komoditas tumbuhan dalam bentuk tabel rincian komoditas tumbuhan yang dimana dari seluruh data lalu lintas komoditas pertanian yang ada akan diambil seluruh data komoditas tumbuhan dan dari data tersbut sistem akan mengelompokkan kembali secara rinci data tersebut ke dalam beberapa kategori diantaranya Bibit Tumbuhan, Hasil Tanaman Hidup (HTH), Hasil Tanaman Mati (HTM) dan Benda Lainnya.

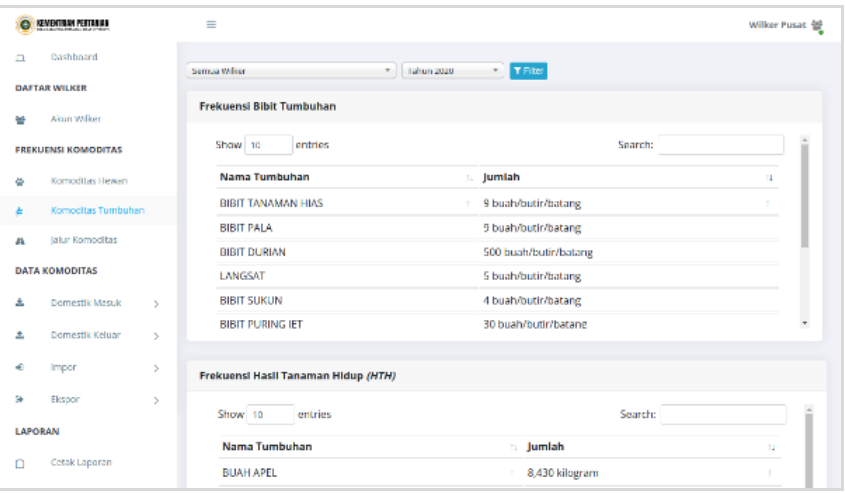

Gambar 17. Frekuensi Rincian Komoditas Tumbuhan

Pada halaman jalur komoditas yang pada Gambar 18, akan menampilkan hasil pengelompokkan setiap jalur dari lalu lintas komoditas pertanian yang dimana hasil tersebut ditampilkan dalam bentuk tabel rincian jalur yang dilalui oleh setiap komoditas pertanian yang dimana jalur tersebut dibagi menjadi empat jalur diantaranya Domestik Masuk (DOMAS), Domestik Keluar (DOKEL), Impor dan juga Ekspor. Untuk jalur DOMAS menjelaskan tentang lalu lintas komoditas yang masuk ke dalam wilayah Maluku Utara dan berasal dari lingkup dalam negeri. Untuk jalur DOKEL menjelaskan tentang lalu lintas komoditas yang keluar dari wilayah Maluku Utara dan menuju daerah lain yang berasal dari lingkup dalam negeri. Untuk jalur Impor menjelaskan tentang lalu lintas komoditas yang masuk ke dalam wilayah Maluku Utara dan berasal dari luar negeri. Untuk jalur Ekspor menjelaskan tentang lalu lintas komoditas yang keluar dari wilayah Maluku Utara dan menuju ke negara lain. Setiap jalur yang ada terbagi atas dua jenis komoditas yakni hewan dan tumbuhan.

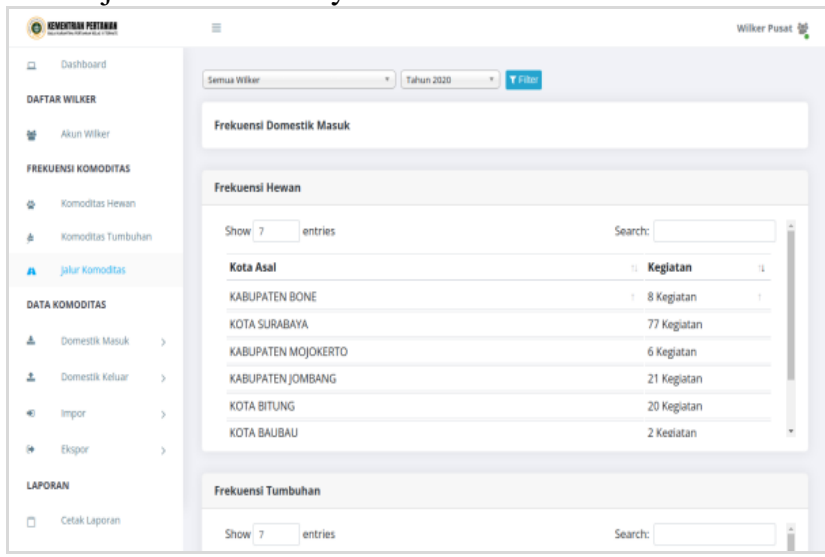

Gambar18. Frekuensi Rincian Jalur Komoditas

\section{B. Hasil Pengujian}

Dari perancangan tersebut diperoleh beberapa hasil pengujian rancang bangun aplikasi lalu lintas komoditas pertanian. Hasil dari aplikasi ini telah sesuai dengan desain yang telah dirancangan sebelumnya. Berikut detail hasil pengujian aplikasi yang ada pada Table 1 . 
Tabel 1. Hasil Pengujian Aplikasi Lalu lintas Komoditas Pertanian

\begin{tabular}{|c|c|c|c|c|}
\hline No & Tujuan & Input & Harapan & Output \\
\hline 1. & $\begin{array}{l}\text { Balai Karantina } \\
\text { Pertanian Kelas } \\
\text { II Ternate dapat } \\
\text { monitoring data } \\
\text { pergerakan lalu } \\
\text { lintas pertanian. }\end{array}$ & $\begin{array}{l}\text { - Tahun Periode } \\
\text { - Nama wilker } \\
\text {-Data lalu lintas } \\
\text { komoditas }\end{array}$ & $\begin{array}{l}\text { Sistem akan } \\
\text { menampilkan } \\
\text { setiap data lalu } \\
\text { lintas komoditas } \\
\text { pertanian yang } \\
\text { diimport, baik } \\
\text { komodtitas } \\
\text { pertanian yang } \\
\text { masuk maupun } \\
\text { keluar dari } \\
\text { wilayah Maluku } \\
\text { Utara }\end{array}$ & $\begin{array}{l}\text { Uji } \\
\text { Berhasil }\end{array}$ \\
\hline 2. & $\begin{array}{l}\text { Balai Karantina } \\
\text { Pertanian Kelas } \\
\text { II Ternate dapat } \\
\text { lebih cepat } \\
\text { memproses } \\
\text { rekapitulasi data } \\
\text { pergerakan lalu } \\
\text { lintas pertanian. }\end{array}$ & $\begin{array}{l}\text { - Tahun } \\
\text { Periode } \\
\text { - Nama wilker } \\
\text { - Data lalu lintas } \\
\text { komoditas }\end{array}$ & $\begin{array}{l}\text { Sistem akan } \\
\text { merekap dan } \\
\text { mengelompokkan } \\
\text { setiap data lalu } \\
\text { lintas komoditas } \\
\text { pertanian yang } \\
\text { diimpor kedalam } \\
\text { aplikasi } \\
\text { berdasarkan jalur } \\
\text { kategori DOMAS, } \\
\text { DOKEL, Impor } \\
\text { dan Ekspor serta } \\
\text { berdasarkan jenis } \\
\text { komoditas Hewan } \\
\text { dan Tumbuhan }\end{array}$ & $\begin{array}{l}\text { Uji } \\
\text { Berhasil }\end{array}$ \\
\hline 3. & $\begin{array}{l}\text { Menyajikan } \\
\text { grafik data lalu } \\
\text { lintas } \\
\text { komoditas } \\
\text { pertanian pada } \\
\text { Balai } \\
\text { Karantina } \\
\text { Pertanian } \\
\text { Kelas II } \\
\text { Ternate }\end{array}$ & $\begin{array}{l}\text { - Tahun Periode } \\
\text { - Nama wilker } \\
\text { - Data lalu } \\
\text { lintas } \\
\text { komoditas }\end{array}$ & $\begin{array}{l}\text { Sistem akan } \\
\text { menampilkan } \\
\text { rincian data lalu } \\
\text { lintas komoditas } \\
\text { berupa tampilan } \\
\text { grafik yang } \\
\text { mudah dibaca dan } \\
\text { dipahami }\end{array}$ & $\begin{array}{l}\text { Uji } \\
\text { Berhasil }\end{array}$ \\
\hline
\end{tabular}

\section{Pembahasan}

Pada pembahasan rancang bangun aplikasi lalu lintas komoditas pertanian, akan dibahas beberapa hal diantaranya sebagai berikut:

1. Penelitian ini menghasilkan rancang bangun aplikasi lalu lintas komoditas pertanian yang berbentuk website. Beberapa hal pendukung digunakan pada perancangan aplikasi ini antara lain meliputi kebutuhan fungsional, kebutuhan non fungsional, Use Case Diagram, Activity Diagram, Sequence Diagram dan Class Diagram. Selain itu terdapat pula hasil implementasi sistem, integrasi dan pengujian sistem, serta evalusai.

2. Aplikasi lalu lintas komoditas pertanian dirancang untuk membantu kegiatan monitoring data lalu lintas komoditas pertanian yang ada dalam wilayah Maluku Utara. Selain itu aplikasi ini juga dirancang untuk mempermudah proses kegiatan rekapitulasi data lalu lintas komoditas pertanian kedalam beberapa sub kategori diantaranya kategori komoditas dan kategori jalur komoditas.

3. Dalam penggunaannya, setiap user yang ada dalam aplikasi ini dibagi menjadi dua role yang memiliki tugas dan fungsinya masing-masing diantaranya supervisor dan administrator wilker. Pada bagian supervisor hanya dipegang oleh seorang admin yang berdomisili di kator pusat, sedangkan untuk administrator wilker akan dipegang oleh seorang admin yang berada di setiap wilker yang ada di wilayah Maluku Utara.

4. Pada bagian supervisor bertugas untuk mengontrol, memonitoring dan mencetak seluruh data lalu lintas komoditas yang dimana data-data tersebut merupakan penggabungan data dari setiap administrator wilker. Selain itu, supervisor juga bertugas untuk melakukan proses pembuatan akun baru yang nantinya akan digunakan oleh administrator wilker. Dalam proses pembuatan akun ini diperlukan beberapa data inputan diantaranya: lokasi wilker, nama calon administrator wilker, email wilker, username dan password.

\section{KESIMPULAN}

Pengembangan sistem informasi yang ada dalam penelitian ini menggunakan beberapa tahapan seperti komunikasi, perencanaan pemodelan serta tahap konstruksi. Berdasarkan hasil ujicoba dan evaluasi terhadap rancang bangun aplikasi lalulintas komoditas pertanian untuk memantau dan merekap kegiatan lalulintas komoditas pertanian pada Balai Karantina Pertanian Kelas II Ternate, maka dapat diambil kesimpulan bahwa aplikasi ini dapat menyelesaikan permasalahan yang selama ini terjadi dalam proses pemantauan data lalulintas komoditas pertanian, yang diantaranya sebagai berikut:

1. Balai Karantina Pertanian Kelas II Ternate dapat monitoring grafik pergerakan data lalu lintas pertanian dalam wilayah Maluku Utara.

2. Aplikasi ini dapat mempercepat proses rekapitulasi data pergerakan lalu lintas pertanian yang ada dalam lingkup kerja Balai Karantina Pertanian Kelas II Ternate.

3. Memudahkan Balai Karantina Pertanian Kelas II Ternate dalam pemenuhan permintaan data lalulintas komoditas pertanian dari beberapa instansi seperti Badan Pusat Statistik (BPS), Kantor Layanan Pajak Maluku Utara, serta Pusat Data dan Informasi Kemetrian Pertanian (PUSDATIN).

\section{REFERENSI}

[1] Ade Suryadi, Y. S. (2019). Rancang Bangun Sistem Pengelolaan Arsip Surat Berbasis Web Menggunakan Metode Waterfall. JURNAL KHATULISTIWA INFORMATIKA, V OL. VII, NO. 1, 13-21.

[2] Badan Karantina Pertanian. (2017). Profil Organisasi. Retrieved from Badan Karantina Pertanian: 
https://karantina.pertanian.go.id/page-8-profil-

organisasi.html

[3] Balai Karantina Pertanian Kelas II Ternate. (2015).

Rencana Strategis BKP Ternate. Retrieved from http://sakip.pertanian.go.id/:

http://sakip.pertanian.go.id/admin/file/Rencana\%20Strat egis\%20BKP\%20Ternate.pdf

[4] Balai Karantina Pertanian Kelas II Ternate. (2021). Profil Balai. Retrieved from Balai Karantina Pertanian Kelas II Ternate: https://ternate.karantina.pertanian.go.id/profil-balaikarantina-pertanian-kelas-ii-ternate/

[5] Balai Karantina Pertanian Kelas II Ternate. (2021) Wilayah Kerja. Retrieved from Balai Karantina Pertanian Kelas II Ternate: https://ternate.karantina.pertanian.go.id/wilayah-kerja/

[6] Faisal, M. (2019). Rancang Bangun Sistem Informasi Housekeeping Inventory. Jurnal Infortech, Vol 1 No.1, 28-34.

[7] Fredisen. (2021). Rancang Bangun Sistem Informasi Produk Dan Pemasaran Pertanian Berbasis Web. Journal Innovation Informatics, 1-9.

[8] Imroatus Sholikhah, M. S. (2017). Aplikasi Pembelian dan Penjualan Barang. Jurnal Teknik Komputer AMIK BSI, 16-23.

[9] Juniardi Dermawan, S. H. (2017). Implementasi Model Waterfall Pada Pengembangan Sistem Informasi Perhitungan Nilai Mata Pelajaran Berbasis Web Pada Sekolah Dasar Al-Azhar Syifa Budi Jatibening. Paradigma Vol. 19, No. 2, 142-147.

[10] Maulani, J. (2020). Penerapan Metode Waterfall Pada Pengembangan Aplikasi. Technologia Vol 11, No. 2, 64-70.

[11] Muhamad Tabrani, E. P. (2017). Penerapan Metode Waterfall. Jurnal Inkofar, 31-38.

[12] Sania, H. P. (2020). Sistem Informasi Lalu Lintas Ternak (Studi Kasus Dinas Pertanian dan Peternakan Kayon Utara) . Jurnal Sistem dan Teknologi Informasi , 58-67. 